\title{
An Ecofeminist Analysis of the Movie Moana
}

\section{Mariamma Angel A}

Student

Pondicherry University Affiliated

Tagore Govt. College of Education

Andaman and Nicobar Islands, India

adzchoir796@gmail.com

\section{Abstract}

This paper attempts to explore the movie Moana from an eco-critical perspective wherein the concepts of domination of nature by mankind will be highlighted. It also examines the movie through a feminist point of view which foreshadows the subjugation of women by men that is prevalent in the movie. It puts forth the issues that prevails in the society and relates the movie with the present scenario of the society. This movie showcases the belief of deep ecology which says that everything in earth has life of its own and the entire universe is in harmony with each other. Ecosophy or ecophilosophy as described by Arne Naess is a term which examines Nature and our relation to it, it also signifies the philosophy of harmony in the entire ecosystem ("Ecosophy"). This wisdom of ecology is predominantly revealed by the female protagonist Moana in the movie Moana. This paper traces the instances from the movie that displays the consequences of interaction of human with Nature and the exploitation of both women and Nature due to the strong hold of the patriarchal attitude that a man believes within.

Keywords: Eco-Feminist, Ecological Crisis, Anthropocene. 


\section{Introduction}

The Disney movie Moana depicts the life of people who belonged to Polynesian culture in which the primary occupation of the people was seafaring, oriented towards exploration of oceans. These indigenous people have their own sophisticated navigation system of observing stars, sea waves and the flight pattern of birds. The plot begins by a story shared by the grandmother of Moana to her about their age old culture of seafaring and the mother island, Tefiti who has become Teka now due to the consequences of losing her heart which was stolen by the demigod of wind and sea, Maui. Moana is the daughter of the chief of her island who restores the heart and brings tranquility and peace again in the island by saving the people from the vengeful blight caused by Teka.

Eco- Feminist Perspective

Vandana Shiva in her essay "Staying Alive: Women, Ecology, and Development" discusses the value of interdependency that is shared by both the women and Nature where both produce and provide sustenance (Ecofeminism). In Moana, one could notice how Moana finds a connection with the ocean even when she wasn't aware of her parental occupation. Through her songs she expresses her feelings that she feels like the ocean is calling her. Tefiti is considered to be the nature goddess who nurtures and her heart is regarded to possess the power to create life and to bring other islands into existence. Nature as Prakriti is an expression of Shakti, the power which could not only create life but also destruct it if the harmony is disturbed and this instance could be predominantly witnessed in Moana.Tefiti becomes violent as Maui steals the heart from her. This act of stealing could be correlated to the act of domination of nature at the hands of mankind. He considers Moana to be weak and docile as she is a woman and refuses to help her to restore the heart. This patriarchal attitude is also witnessed in the chief of the island, being the father of Moana, he denies to allow 
Moana to go and help the citizen of her island, because he thinks it to be impossible for her to do that as once when he and his friend himself tried, he lost his friend.

But after the climax one could notice the spiritual interaction between Teka and Moana in which Moana restores the heart and they both are seen as pressing their forehead and nose signifying the intricate bond shared by them. This instance could also be correlated with the notion that Moana by touching the forehead of Teka is able to empathize, seek forgiveness for the disgraceful act of mankind, who considered themselves as superior to Nature and tried to domesticate it within the clutches of mankind. It also highlights the ecosophy, the wisdom of ecology which is inherently present in Moana due to which she was able to calm down the furious Teka and bring Tefiti back to life.

Ecological Crisis

In the "Canonical Western Philosophy", Warren speaks about a "Conceptual Framework" which descibes how rationality is not only the hallmark of human beings, but also the attitude that human beings are superior to Nature and all other non-living beings. A conceptual framework is a set of beliefs, attitudes, assumptions that reflects how one perceives one's own self and the world around them. In an oppressive conceptual framework, unjustified domination and subordination is justified, explained and well maintained (Warren 2015). It is passed on from generation after generation. The massive greed for power and dominance has led to massive destruction of the island. People in the island are seen starving as their sources of food have become extinct. The act of Maui to gain power over the universe by taking something vital which was the life giving force from Tefiti led the entire island to face the wrath of Teka. This is the notion of a man showcased through Maui to tame nature and women as a whole and by doing that he thinks he could create life with the heart of Tefiti. Rather he loses his own power.

Anthropocene 
Plumwood argues that deep ecology's criticism of anthropocentrism fails to see that the canonical philosophy of anthropocentrism has functioned historically as andropocentrism which denotes male-centered thinking (1993). There is an instance in the movie where in one could notice how the islanders, specially Maui don't realize the fact that they are just one strand of the greater biotic web, due to this reason they don't empathize with nature and treat it as a commodity. Karen J. Wareen has argued that "the logic of domination" plays a crucial role in exploitation and oppression (11). The root cause of marginalization and oppression is power. She states that dualism leads to value hierarchy, which in turn enables people to justify the subordination of nature and women. In Moana it is depicted that the Moana has the indigenous knowledge of conserving Nature, it has been bestowed on to her by her grandmother Tala, who orally transmitted their cultural heritage, the Mauri culture to her. Thus depicting the fact that women are not only the conserver of Nature but also their own culture. Male in the society assumes and claims themselves to be the sole conserver of their culture, but in the movie Moana, Moana is witnessed to be the one who is able to bring life to her family's tradition of seafaring which everyone left astray as they were afraid of the rage of Teka. By restoring the heart, she not only brought harmony in Nature, but also managed to survive inspite of facing the obstacles towards her destiny. She had belief in herself that she could do that. She proved herself to be the real leader. Her strong determination and trust in the words of her grandmother Tala, lead her to save the life of the people in her island and also the cosmos of the other islands which were once effected by the anger of Teka.

Conclusion

Moana restores the heart of Tefiti inspite of all the trials and tribulations she has to come through. She was told by Tala that she is the chosen one who could redeem the island from the wrath of Teka. One could draw references to Mother Mary as well, who is considered to be the chosen one in Christian mythology, who gave birth to Jesus, who gave 
away his life for the redemption of mankind. Even Moana could be considered as the one who restored life and harmony by bringing the heart of Tefiti back to her. Women in general thus could be regarded as the custodians of biodiversity. As human beings and the natural worlds are intricately related to each other for their existence, therefore it is the prime neccissity to maintain equilibrium in order to preserve the natural world and the mankind. Thus sustainable development with a biocentric or ecocentric approach is the best way to preserve the Nature which defies the radical human centred attitude. It also facilitates the coexistence of both the life forms in the earth's ecological system without creating a barrier in one another's life. 


\section{Works Cited}

“Ecosophy.” Environmental Encyclopedia. 29 Dec. 2021, Encyclopedia.com.

www.encyclopedia.com/environment/encyclopedias-almanacs-transcriptd-andmaps/ecosophy.Accessed 17 Jan 2022.

Mies, M. and V. Shiva, Ecofeminism, Zed Books, 2014, Academia, www.academia.edu/37778615/_EcoFeminism_Zed_books_2014_By_Maria_Mies_an d_Vandana_Shiva_with_a_Foreword_by_Ariel_Salleh._Ebook_download_PDF. Accessed 17 Jan 2022.

Plumwood, Val. "Dualism: the Logic of Colonization." Feminism and the Mastery of Nature, Routledge, 1993. pp. 42-44. Bookfi, en.bookfi.net/book/1200752.

Warren, Karen J, "Feminist Environmental Philosophy." The Stanford Encyclopedia of Philosophy, edited by Edward N. Zalta, Stanford University, 2015, Environment And Society, plato.stanford.edu/archives/sum2015/entries/feminism-environmental. 